\title{
The book under the couch: what disturbs the reader
}

\author{
What Disturbs Our Blood: A Son's Quest \\ to Redeem the Past \\ James FitzGerald \\ Random House Canada; 2010
}

$\mathrm{H}$ orror was my reaction to James FitzGerald's revelations. Part way through, I shoved his book underneath the couch, where it lay for months. I could not deal with the atrocities performed in the name of "medicine."

Brutal. Electrifying. Melancholy. Illuminating. A scholarly masterpiece.

FitzGerald's book is two stories. He weaves his search for the truth about the tortured lives of his grandfather and father - and the often unrecognized accomplishments of these two Canadian medical pioneers - with vivid stories of medical history.

The author's grandfather, singleminded and self-sacrificing, was the founder of Connaught Laboratories and director of the University of Toronto School of Hygiene. Gerry FitzGerald was considered by many to be the father of preventive medicine. The laboratory's vaccines, serums and antitoxins were provided free to all Canadians - a radical concept espoused by the elder FitzGerald. His death came suddenly and unexpectedly. The reasons

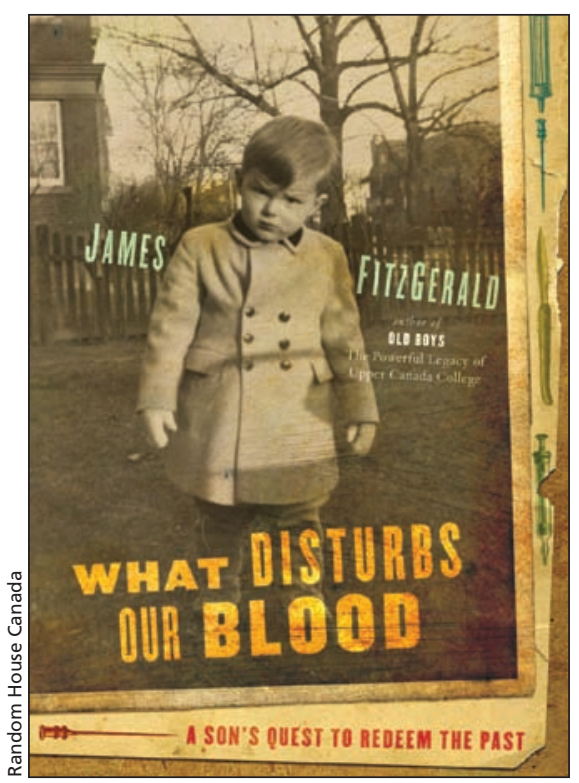

and cause remained unspoken.

The author's father was an allergist. In the 1960s this was a specialty as indefinable and strange as was Jack FitzGerald. Like his father before him, Jack held strong to his beliefs. A vehement defender of private medicine, he opened a private allergy extract lab because extracts produced by commercial laboratories had no set standards. He fought to disprove that allergic reactions were due to nerves. Stress and depression were effects, not causes, he argued. Sadly, he slipped into mental illness, as had his father before him, and disintegrated gradually, silently. Both men were eventually forgotten - in most history books, and in the Canadian psyche - hidden away like the shame and darkness of their mental illnesses.

The author, haunted by his family's carefully hidden history, exposes the mania and treatments (or lack thereof) of his grandfather and father. In so doing, he tears apart the underbelly of 20th century medicine. We get an insider's look at the opposing views on mental illness prevalent in the early 1900s.

We learn of the battle between Freud, with his disturbing theories, and the medical establishment, with its often radical procedures: lobotomy, insulin shock or the removal of gallbladders, stomachs, testicles, ovaries or colons in an attempt to "rip out" the root cause of mental illness - poisonous toxins.

FitzGerald takes us down the road of insanity walked by two greats of Canadian medicine and opens our eyes to a history left behind. As with his valiant work on Upper Canada College, the silence has been broken. This book will rattle your soul.

\section{Jen Raiche}

Freelance writer and editor

Ottawa, Ont.

CMAJ 2011. DOI:10.1503/cmaj.110646

\section{The forbidden legacy of madness}

An interview with James FitzGerald, the author of What Disturbs our Blood: A Son's Quest to Redeem the Past.

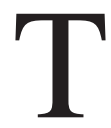
here are few among us who have never imagined living someone else's life. Whether roused by envy, dread or the odd idle daydream, it's easy to stray from the hand we've been dealt, and cast ourselves according to whim.

Unless, of course, you are James FitzGerald. Son and grandson to two medical giants, James grew up haunted by a dark family secret. Conditioned to shun all things wretched, he chose instead to ques- tion, to probe the forbidden legacy.

No small feat. His father and grandfather, both doctors, at the peak of their success, went mad - all record of their achievements shrouded in medical archives.

It is a fascinating story - the result of which is the book, What Disturbs Our Blood, in talks to become the sub- 
ject of a documentary. Bold and meticulously researched, it offers staggering insights into how the medical establishment has viewed mental illness, particularly among its own, and an engrossing look at Canada's medical history.

When I first meet James FitzGerald, he strikes me as a lanky, modernday warlock figure; a cross between Harry Potter's Dumbledore and the house elf Dobby. His eyes are intense, his height imposing, but his manner is humble and gracious. We are discussing a series of interviews for a radio broadcast. Our first conversation lasts four hours.

$\mathrm{He}$ is a superb storyteller. With very little prodding, he browses through his memory bank like some of us do a bookstore, recounting tales with effortless ease. The book was a result of a 15-year journey, he tells me, an extraordinary one, no less. He takes me on part of that journey, enacting many of the characters he talks about, and I sit, transfixed. I tell him he should consider launching a one-man play, and while the possibility amuses him, he appears to take my suggestion seriously.

$\mathrm{He}$ is a man of many resources and a will of steel. Believing his future lay in his past, he threw himself headlong into
From there, it mushroomed. Gerald FitzGerald was part of the "mental hygiene" movement, of which eugenics was a part. "The Nazis have always been associated with eugenics," James tells me, "but it really got its start in North America." Embraced by his grandfather's colleagues among them CB Farrar - the movement ultimately led to sterilization laws in Alberta and BC. "Selective ideas about who was appropriate to breed existed in the left wing as much as the right," he emphasizes. "These ideas led to racism and ultimately, to death camps."

The irony of his grandfather's early career was not lost on James and indeed, provided much of the fuel that drove his research. Gerald FitzGerald would one day lose his mind. Before that, however, he would transform the public health system in Canada, saving untold lives by developing vaccines. His father, a renowned allergist, met a similar fate, going insane at the pinnacle of his career. A hipster in his private life, he smoked opium to battle migraines; his addictions eventually got the better of him. Neither man received a definitive diagnosis.

The more I get to know James, the more I am struck by his relentlessness; his determination, as he puts it, "to cir-

\section{"The 'haunted house of my childhood' is a metaphor for my body, and writing the book was a quest to 'inhabit my own body.'"}

research. He takes me back to the 1850s, when the 999 Queen Street Lunatic Asylum was born, and the "Victorian idealism of the time was very humane toward the mad." By the early 1900s, however, conditions had become brutal. In 1905, German scientists discover the germ for syphilis in the brain, which caused insanity. His grandfather, a young neuropathologist, entered the picture at this key time in history, part of a group of leading-edge, elite doctors excited by the prospect that madness was bacteriological. "The physical roots of madness became his holy grail," he recalls. cumvent the generational drama that threatened to render me a lifelong visitor on this planet." I know exactly what he means, but I want him to elaborate anyway.

"I felt as if I was living someone else's life. Like an actor following a script," he admits. "There was a profound disconnect."

"So you had to dig."

"My sanity depended on it. The 'haunted house of my childhood' is a metaphor for my body, and writing the book was a quest to "inhabit my own body.' I needed to crawl inside the alien skin of my father and my grandfa-

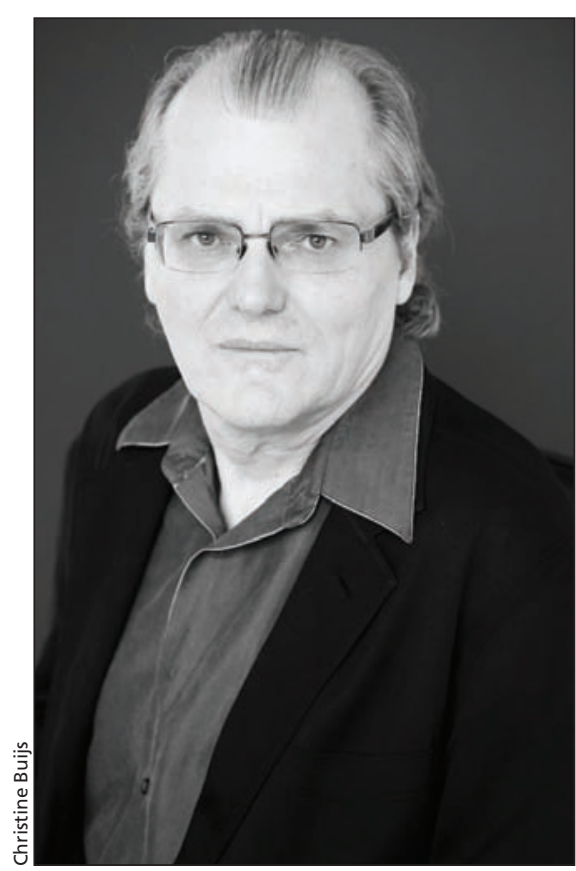

James FitzGerald

ther. The book took off when I gave myself permission to imagine what was in their heads when they were cracking up. What I learned was horrible, but it freed me."

The result of that research is a beautifully written, disturbing exposé of how our perceptions of mental illness have shaped treatment over the last 100 years. We talk about what defines "treatment" today, and how so much of it boils down to behaviour modification and little else. And we talk about the lingering stigma.

"I attended a nonfiction award ceremony in Vancouver recently, and met the Premier of British Columbia, Gordon Campbell," James recounts. "He had read my book, and approached me to say that his physician father had killed himself when he was just a child. He then went on to tell this story in his keynote speech. It had been a family secret for the longest time. I was very touched by that."

\section{Jessica Mendes \\ Freelance writer \\ Toronto, Ont.}

Jessica Mendes is host and producer of Being There on CIUT Radio, which broadcasts on the Internet.

CMAJ 2011. DOI:10.1503/cmaj.110681 